Mrs Patricia Wallace for clerical assistance, and Mrs Cathy Harwood for typing the manuscript.

1 AIDS Group of the United Kingdom Haemophilia Centres. Seropositivity for HIV in UK haemophiliacs. Proc $R$ Soc Lond [Biol] (in press)

2 Peto R. Experimental survival curves for interval-censored data. Applied Statistics 1973;22:86-91.

3 Turnbull BW. The empirical distribution function with arbitrarily grouped, censored and truncated data. Fournal of the Royal Statistical Societ 1976;38:B290-5

4 Brookmeyer R, Goedert JJ. Censoring in an epidemic with an application to haemophilia-associated AIDS. Biometrics (in press).

5 Cox DR, Oakes D. Analysis of survival data. London: Chapman and Hall, 1984.

6 SAS Institute. SAS users guide: statistics. Cary, North Carolina: SAS Institute, 1985.

7 Rizza CR, Spooner RJD. Treatment of haemophilia and related disorders in Britain and Northern Ireland during 1976-80: report on behalf of the directors of haemophilia centres in the United Kingdom. $\mathrm{Br} M e d \mathcal{F}$ 1983;286:929-33.

8 Brookmeyer R, Gail MH, Polk BF. The prevalent cohort study and the acquired immunodeficiency syndrome. Am $\mathcal{F}$ Epidemiol 1987;126:14-24.

Medley GF, Anderson RM, Cox DR, Billard L. Incubation period of AIDS in patients infected via blood transfusion. Nature 1987;328:719-21.

10 Giesecke J, Scalia-Tomba G, Berglund O, Berntorp E, Schulman S, Stigendal L. Incidence of symptoms and AIDS in 146 Swedish haemophiliacs and blood transfusion recipients infected with human immunodeficiency virus. BrMed f 1988;297:99-102.

11 Moss AR, Bachetti P, Osmond D, et al. Seropositivity for HIV and the development of AIDS or AIDS related condition: three year follow up of the San Francisco General Hospital cohort. Br Med f 1988;296:745-50.

12 Eyster ME, Gail MH, Ballard JO, Al-Mondhiry H, Goedert JJ. Natural history of human immunodeficiency virus infections in hemophiliacs: effects of T-cell subsets, platelet counts, and age. Ann Intern Med 1987;107:1-6. 13 Johnson RE, Lawrence DN, Evatt BL et al. Acquired 1987;107:1-6. syndrome among patients attending hemophilia treatment centres and syndrome among patients attending hemophilia treatment centres an mortality experience of hemophiliacs in the Unired Stars. Am $f$ Epidemio

14 Lui KJ, Peterman TA, Lawrence DN, Allen JR. A model-based approach to characterize the incubation period of paediatric transfusion-associated acquired immunodeficiency syndrome. Stat Med 1988;7:395-401.

15 Lui KJ, Lawrence DN, Morgan WM, Peterman TA, Haverkos HW, Bregman DJ. A model-based approach for estimating the mean incubation period of transfusion-associated acquired immunodeficiency syndrome. Proc Nat Acad Sci USA 1986;83:3051-5.

16 McCormick A. Trends in mortality statistics in England and Wales with particular reference to AIDS from 1984 to 1987. Br Med f 1988;296: 1289-92.

17 Ragui MV, Kingsley LA, Kiss JE, Spero JA, Lewis JH. HIV-related deaths in HIV antibody-positive haemophiliac patients. Lancet 1987:ii:100.

(Accepted 14 February 1989)

\title{
New regression equations for predicting peak expiratory flow in adults
}

\author{
A J Nunn, I Gregg
}

\begin{abstract}
An earlier study of peak expiratory flow (PEF) in normal adults contained too few men aged over 55 and women aged over 65 for the regression equations to be used for prediction in older people. A subsequent study was therefore carried out on an additional 23 men and 29 women aged 55 or over who were lifelong non-smokers and satisfied the same strict criteria of normality that had been used in the original study. The data from both studies were combined and a new model used to calculate equations for the regression of PEF on age and height in the two sexes. With this model predicted values could be derived for men and women aged between 15 and 85 . These new equations gave predicted values in men and women aged less than $\mathbf{5 5}$ and 65 , respectively, which were almost identical with those reported previously.
\end{abstract}

The new regression equations for PEF enable values to be predicted for people aged $15-85$ and so enhance the accuracy of testing in the elderly.

\section{Introduction}

Measurement of peak expiratory flow (PEF) by the Wright meter ${ }^{1}$ is invaluable for identifying and assessing airflow obstruction in clinical practice. ${ }^{2}$ The introduction of the mini Wright meter ${ }^{3}$ has resulted in the test being used increasingly by general practitioners.

An observed PEF must be assessed by comparing it with the subject's predicted PEF, which is taken as the mean PEF attainable by "normal" people of the same ethnic origin, sex, age, and body build. The distributors of the Wright and mini Wright meters provide a nomogram for predicting PEF based on a study (reported by us in 1973) t $^{4} 202$ men and 199 women who were lifelong non-smokers and who fulfilled other stringent criteria of "normality." That study, however, contained few men aged over 55 and women aged over 65 , so that the equations were not valid for predicting PEF in older people.

Knowledge of normal ventilatory function is particularly important in older people because of their high prevalence of chronic bronchitis and emphysema. We therefore studied additional men aged 55 or over and women aged 65 or over who fulfilled the same selection criteria as in our original study.

In this paper we report new equations for the regression of PEF in men and women which were calculated from the combined data of the original and present studies. We compare the new regressions with those which we reported previously $y^{+}$and also with those of other workers who did not restrict their series to non-smokers. In a subsidiary study (reported in our accompanying paper ${ }^{5}$ ) we used the new equations to investigate the effects of smoking on ventilatory function in elderly men and women who, apart from being smokers or ex-smokers, fulfilled all our other criteria of normality.

\section{Subjects and methods}

Between 1975 and 1987 one of us (IG) conducted a search in the course of day to day consultations in two general practices to identify men aged 55 or over, and women aged 65 or over who had never smoked and who denied expectoration, respiratory infection, wheeze, or shortness of breath during childhood or adulthood. The practices, in Kingston upon Thames and Southampton, were similar in their age and social class distribution, and levels of atmospheric pollution were generally low in both areas.

Measurements of PEF were made with three Wright peak flow meters, whose calibration was checked at regular intervals. All the tests were supervised by a single observer (IG), who explained the purpose of the study and then demonstrated the correct manner of performing the test. Subjects were observed while they made several trial attempts in order to detect faults in technique. Once they were able to perform the test correctly they were exhorted to make a maximum effort, and the highest value achieved in three tests in the standing position was recorded to the nearest $5 \mathrm{l} / \mathrm{min}$. Standing height without shoes was measured to the nearest centimetre.

The data from 23 men aged 55 or over and 29 women aged 65 or over who satisfied our criteria of normality were combined with those from the 202 men and 199 women in the original series. In calculating the equations for the regression of PEF on age and height 
in each sex we made the following assumptions: (a) PEF increases to a maximum during early adulthood and thereafter declines with age; $(b)$ at any given age PEF increases with height. These assumptions are satisfied by the model, $\log _{e} P E F=a$ age $+b \log _{e}$ age $+c /$ height $+d$. The method of least squares analysis was used to determine the equations which gave the best fit with the data.

\section{Results}

The table gives the age and sex distribution of the 225 men and 228 women studied. Only seven men were aged 65 or over, whereas the women's ages were more evenly distributed in the older age groups. The equations which gave the best fit with the data were, for men: $\log _{e}$ PEF $(1 / \mathrm{min})=0.544 \quad \log _{e}$ age -0.0151 age $-74 \cdot 7 /$ height $(\mathrm{cm})+5 \cdot 48$; and for women: $\log _{\mathrm{e}} \mathrm{PEF}$ $(1 / \mathrm{min})=0.376 \quad \log _{\mathrm{e}}$ age -0.0120 age $-58 \cdot 8 / \mathrm{height}$ $(\mathrm{cm})+5 \cdot 63$.

Figure 1 shows the observed values of PEF in the men and women plotted against age. The figure also shows the regressions of PEF on age (obtained from the

Age distribution of 225 men and 228 women who were lifelong non-smokers and who satisfied strict criteria of normality

\begin{tabular}{lcc}
\hline Age $($ years $)$ & No $(\%)$ of men & No $(\%)$ of women \\
\hline $15-24$ & $72(32)$ & $71(31)$ \\
$25-34$ & $51(23)$ & $33(14)$ \\
$35-44$ & $44(20)$ & $48(21)$ \\
$45-54$ & $29(13)$ & $26(11)$ \\
$55-64$ & $22(10)$ & $22(10)$ \\
$65-74$ & $7(3)$ & $14(6)$ \\
$\geqslant 75$ & & $14(6)$ \\
\hline Total & $225(100)$ & $228(100)$
\end{tabular}

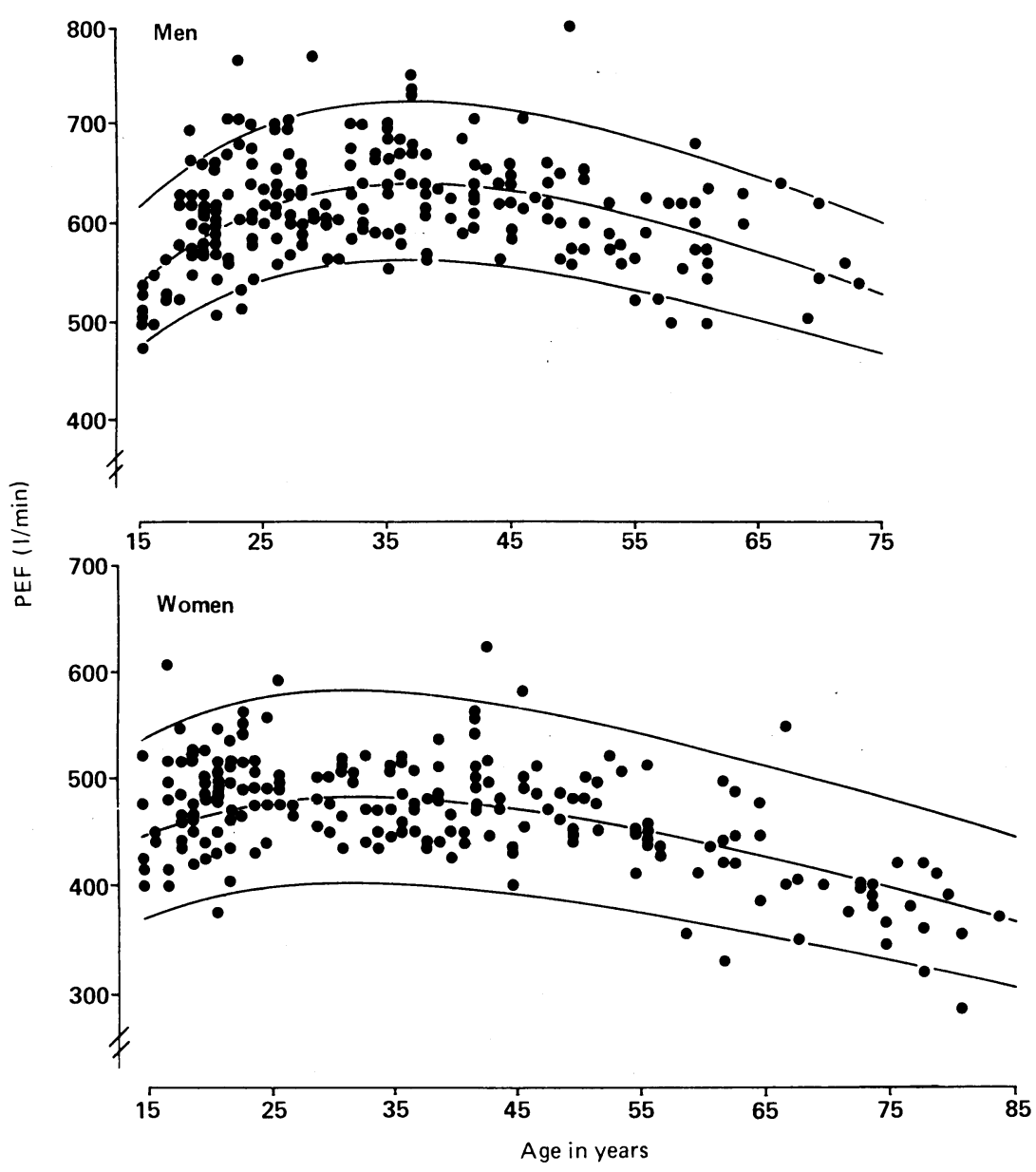

FIG 1-Observed values of peak expiratory flow (PEF) in 225 men and 228 women who had never smoked and who fulfilled other strict criteria of normality (see text). Regression curves and $90 \%$ confidence intervals drawn for mean heights of men and women $(177 \mathrm{~cm}$ and $162 \mathrm{~cm}$, respectively) new equations) for the mean heights of the men (177 $\mathrm{cm})$ and women $(162 \mathrm{~cm})$ together with their $90 \%$ confidence intervals. Maximum values of PEF in both sexes occurred at around 30-35 years of age. After about age $50 \mathrm{PEF}$ fell by about $4 \mathrm{l} / \mathrm{min}$ a year in men and $2.5 \mathrm{l} / \mathrm{min}$ a year in women. In both sexes the lower $90 \%$ confidence limits (below which only $5 \%$ of values from normal subjects would be expected to fall) were roughly $70-80 \mathrm{l} / \mathrm{min}$ below predicted and did not differ greatly with age. Of the total variation in PEF, only a small part ( $30 \%$ in men, $28 \%$ in women) was accounted for by differences in age and height.

Figure 2 shows the new regressions for men with a height of $175 \mathrm{~cm}$ and women with a height of $160 \mathrm{~cm}$ compared with those which we reported previously.

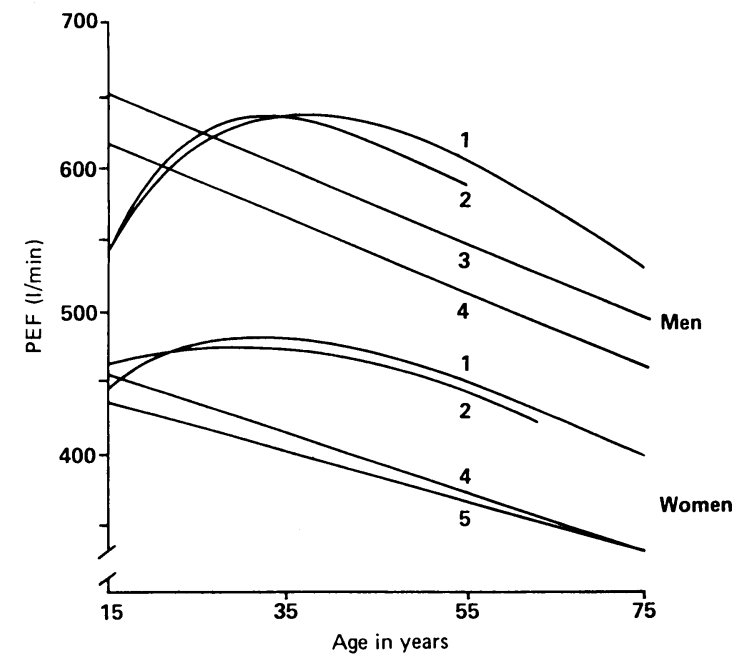

FIG 2-Mean peak expiratory flow (PEF) in men with height of $175 \mathrm{~cm}$ and women with height of $160 \mathrm{~cm}$ derived from new regression equations compared with those described by us in $1973^{3}$ and by other workers. Men: I=Present series, 2=Gregg and Nunn (1973), $3=$ Leiner et al, ${ }^{\circ} 4=$ European Community for Coal and Steel. Women: $1=$ Present series, $2=$ Gregg and Nunn (1973), $4=$ European Community for Coal and Steel, ${ }^{\times} 5=$ Pelzer and Thomson ${ }^{7}$

In men the largest difference was about $15 \mathrm{l} / \mathrm{min}$ at 45-55 years of age, whereas in women it was about $10 \mathrm{l} / \mathrm{min}$ during adolescence and between the ages of 25 and 35 . Figure 2 also shows the regressions published by some other workers ${ }^{6-8}$ for men and women of the same heights.

\section{Discussion}

The problems of defining "normality" for the purpose of establishing reference values for pulmonary function have been discussed by Miller ${ }^{9}$ and Lebowitz et $a l .{ }^{10}$ Lifelong non-smoking was the principal criterion that we used in selecting subjects for both our original ${ }^{4}$ and present studies.

It has been contended that predicted values obtained in non-smokers in the general population "reduce their usefulness as indicators of disease." Nevertheless, though data from non-smoking communities of Mormons or Seventh Day Adventists ${ }^{12}$ may be unrepresentative because of factors associated with their genealogy or lifestyle, ${ }^{9}$ it has been shown that smokers who deny cough or other symptoms have significantly lower levels of PEF than non-smokers, ${ }^{13-16}$ even among adolescents. ${ }^{1}$

The effects of smoking on ventilatory function are likely to be particularly great in the elderly by reason of their generally longer exposure. Among older people, especially men, only a small proportion have never smoked. ${ }^{18}$ Their inadequate representation in our original series precluded use of the regression equations for predicting PEF in men aged over 55 and women aged over 65 . We suggested that approxima- 
tions could be made by extending the regression curves linearly beyond these ages, ${ }^{4}$ an expedient that was adopted in the nomogram issued by the distributors of the Wright and mini Wright meters.

The model which we used to calculate the new regression equations was similar to one that Berglund et al used in a study of forced expiratory volume in one second and vital capacity. ${ }^{19}$ In being curvilinear our regressions differ from those of most other workers, ${ }^{6.82021}$ two of which (Leiner et al ${ }^{6}$ in men, Pelzer and Thomson ${ }^{7}$ in women) have been recommended as reference values for predicting PEF. ${ }^{22}$ As pointed out by Brooks and Waller, linear regressions from 20 years of age give falsely high predicted values in adolescents and young adults (fig 2). ${ }^{23}$

Reference values of PEF have been published by a working party of the European Community for Coal and Steel, convened for the purpose of standardising lung function tests. ${ }^{8}$ These were derived by combining data from several studies, all of which had included smokers and ex-smokers unless they admitted to expectoration or gave a history of chest disease. The regressions of the working party and those recommended by Cotes, ${ }^{22}$ which also included smokers, are substantially lower than ours at all ages in both sexes, except in adolescents (fig 2).

In a person with normal bronchi and alveoli the magnitude of PEF is determined by the pressure exerted in a forced expiration and hence the power of the expiratory muscles; it is also influenced by body build and, in particular, thoracic volume. The only conveniently measured index of body build is standing height, but this correlates poorly with thoracic volume. This explains much of the wide variation in PEF which we found among subjects (fig 1), of which our new equations accounted for only slightly more of the variation in men than our original regressions $30 \% v$ $23 \%$ ), whereas in women the amount explained was the same $(28 \%)$

A curvilinear regression of PEF, rising to a maximum by about $30-35$ years, is consistent with increasing body size and muscular power. The generally greater thoracic volumes and muscular power of men accounted for much of the difference in PEF between men and women of the same age and height. Differences of body build are also the probable explanation for the finding that, independently of smoking habit, PEF in Africans, ${ }^{2+27}$ Indians, ${ }^{28} 29$ and Chinese ${ }^{30}$ is lower than in European subjects of corresponding age and height. That these differences are of racial rather than environmental origin is suggested by studies of immigrants to Britain. Asians from the Indian subcontinent and east Africa have been found to have lower values of $\mathrm{PEF}$, forced expiratory volume in one second, and forced vital capacity than those of native Britons or immigrants from the West Indies. ${ }^{31} 32$

Reduced air density at high altitude has little effect on PEF and may be ignored for clinical purposes; values at $3000 \mathrm{~m}$ were only $3.5 \%$ less than at sea level. ${ }^{33}$ On the other hand, voluntary effort has a considerable influence on PEF, which is greater than in other tests of ventilatory function, and it is essential to ensure that subjects make a maximum effort. Close attention must also be paid to the correct technique of performing the test, ${ }^{1}{ }^{10}$ otherwise falsely low values will be obtained.

The measurements of PEF in this study were made with the standard Wright peak flow meter, ${ }^{3}$ whereas most general practitioners use a mini Wright meter. ${ }^{2}$ Though the values given by the two instruments are generally in close agreement, ${ }^{35}$ the mini Wright meter is less robust and apt to lose calibration. ${ }^{36}$

It is a pleasure to thank Mrs Marion Rickman and Miss Deborah Johnson for their help in analysing the data, and the trustees of the Rudolf Friedlaender Memorial Trust for a grant to Mrs Rickman. During this study IG was supported by grants from the Department of Health and Social Security; the Chest, Heart, and Stroke Association; and Clement Clarke International Ltd.

1 Gregg I. The measurement of peak expiratory flow and its applications in general practice. $7 R$ Coll Gen Pract 1964;7:199-215.

2 Wright BM. A miniature Wright peak flow meter. Br Med f 1978;ii:1627-8.

3 Wright BM, McKerrow CB. Maximal forced expiratory flow rate as a measure of ventilatory capacity with a description of a new portable instrument fo measuring it. Br Med f 1959;ii: 1041-7.

4 Gregg I, Nunn AJ. Peak expiratory flow in normal subjects. Br Med $\mathcal{J}$ 1973; iii:282-4.

5 Gregg I, Nunn AJ. Peak expiratory flow in symptomless elderly smokers and ex-smokers. Br Med F 1989;298:1071-2.

6 Leiner GC, Abramowitz S, Small MJ, Stenby VB, Lewis WA. Expiratory peak flow rate. Standard values for normal subjects. Use as a clinical test of ventilatory function. Am Rev Respir Dis 1963;88:644-51.

7 Pelzer AM, Thomson ML. Expiratory peak flow. Br Med 7 1964;ii: 123.

8 Quanjer PH, ed. Standardized lung function testing. Bull Eur Physiopathol Respir 1983;19suppl 5:1-95.

9 Miller A. The use of pulmonary function tests in the evaluation of disease: separating normal from abnormal. Immunology and Allergy Practice 1983;5: separating $305-15$.

10 Lebowitz MD, Quackenboss J, Camilli AE, Bronnimann D, Holberg CJ Boyer B. The epidemiological importance of intraindividual changes in objective pulmonary responses. European fournal of Epidemiology 1987;3 390-8.

11 Morris JF, Koski A, Johnson IC. Spirometric standards for healthy non smoking adults. Am Rev Respir Dis 1971;103:57-67.

12 Laszlo G. Standardised lung function testing. Thorax 1984;39:881-6.

13 Read J, Selby T. Tobacco smoking and ventilatory function of the lungs. BrMed f 1961;ii:1104-8.

14 Zamel N, Youssef HH, Prime FJ. Airway resistance and peak expiratory flow rate in smokers and non-smokers. Lancet 1963;i:1237-8.

15 Huhti E. Ventilatory function in healthy non-smokers and smokers. Scandinavian foumal of Respiratory Diseases 1967;48:149-55.

16 Sluis-Cremer GK, Sichel HS. Ventilatory function in males in a Witwatersrand town. Comparison between smokers and nonsmokers. Am Rev Respir Dis 1968:98:229-39.

17 Backhouse CI. Peak expiratory flow in youths with varying smoking habits. BrMed f 1975;i:360-2.

18 Milne JS, Williamson J. Respiratory function tests in older people. Clin $\mathrm{Sc}_{\mathrm{c}}$ 1972;42:371-81.

19 Berglund E, Birath G, Bjore J, et al. Spirometric studies in normal subjects. Forced expirograms in subjects between 7 and 70 years of age. Acta Med Scand 1963;173:185-92.

20 Ferris BG, Anderson DO, Zickmantel R. Prediction values for screeming test of pulmonary function. Am Rev Respir Dis 1965;91:252-61.

21 Leonards AK. Der maximale Expirationsstrom. Untersuchung der Lungenfunktion bei Gesunden. Acta Allergologica 1966:21:99-138.

22 Cotes JE. Lung function: assessment and application in medicine. 4th ed. Oxford: Blackwell Scientific, 1979.

23 Brooks AGF, Waller RE. Peak flow measurements among visitors to a public health exhibition. Thorax 1972;27:557-62.

24 Elebute EA, Femi-Pearse D. Peak flow rate in Nigeria: anthropometric determinants and usefulness in assessment of ventilatory function. Thorox 1971:26:597-601.

25 Johannsen ZM, Erasmus LD. Clinical spirometry in normal Bantu. Am Rer Respir Dis 1968;97:585-97.

26 Teklu B, Seboxa T, Mills RJ. Peak expiratory flow in normal Ethiopian children and adults in Addis Ababa. BrF Dis Chest 1987;81:176-81.

27 Cookson JB, Blake GTW, Faranisi C. Normal values for ventilatory function in Rhodesian Africans. Br $\mathcal{F}$ Dis Chest 1976;70:107-11

28 Malik SK, Banga N. Peak expiratory flow rates in non-smoking rural males. Indian 7 Chest Dis Allied Sci 1978;24:183-6.

29 Kamat SR, Tyagi NK, Rashid SSA. Lung function in adult subjects. Lung Indiu 1982;1:1-11.

30 Lam KK, Pang SC, Allen WGL, Hill LE, Snell NJC, Nunn AJ. A survey of ventilatory capacity in Chinese subjects in Hong Kong. Ann Hum Biol ventilatory capaci

31 Malik MA, Moss E, Lee WR. Prediction values for the ventilatory capacity in male West Pakistani workers in the United Kingdom. Thorax 1972;27: $611-9$

32 Jackson SHD, Cruickshank JK, Beevers DG, Bannan LT. Ethnic differences in peak expiratory flow rate in Birmingham factory workers. Postgrad Med $\mathcal{f}$ 1983;59:671-3.

33 Forster P, Parker RW. Peak expiratory flow rate at high altitude. Lancel 1983;ii: 100 .

34 Connolly CK. Falsely high peak expiratory flow readings due to acceleration in the mouth. Br Med F 1987;294:285.

35 Morrill CG, Dickey DW, Weiser PC, Kinsman RA, Chai H, Spector SL. Calibration and stability of standard and mini-W' right peak flow meters. Ann Allergy 1981;46:70-3.

36 Oldham HG, Bevan MM, McDermott M. Comparison of the new miniature Wright peak flow meter with the standard Wright peak flow meter. Thorax 1979;34:807-9.

(Accepted 27 February 1989) 